\title{
Nutrient removal effectiveness by riparian buffer zones in rural temperate watersheds: The impact of no-till crops practices
}

\author{
T.R. Aguiar Jr. ${ }^{\mathrm{a}, \mathrm{b}, \mathrm{c}, *}$, K. Rasera ${ }^{\mathrm{a}}$, L.M. Parron ${ }^{\mathrm{c}}$, A.G. Brito ${ }^{\mathrm{d}}$, M.T. Ferreira ${ }^{\mathrm{b}}$ \\ a Federal University of Paraná, Hydrogeological Research Laboratory, Centro Politécnico, 81990-551 Curitiba, PR, Brazil \\ ${ }^{\mathrm{b}}$ University of Lisbon, School of Agronomy, Department of Natural Resources, Environment and Landscape, Tapada da Ajuda, 1349-017 Lisboa, Portugal \\ ${ }^{\mathrm{c}}$ Brazilian Agricultural Research Corporation-EMBRAPA, Forests Department, 83411-000 Colombo, PR, Brazil \\ d University of Lisbon, School of Agronomy, Department of Biosystems Sciences and Engineering, Tapada da Ajuda, 1349-017 Lisboa, Portugal
}

\section{A R T I C L E I N F O}

\section{Article history:}

Received 18 July 2014

Accepted 29 October 2014

Available online 17 November 2014

\section{Keywords:}

Water contamination

Nutrients

No-till systems

Temperate climate zones

Nitrogen

Phosphorus

\begin{abstract}
A B S T R A C T
Riparian buffer zones have the potential to capture chemical contaminants and to mitigate detrimental side-effects in aquatic ecosystems derived from excess fertilizers used in agro-food production. No-till farming systems are well known agricultural practices and are widely used in temperate areas. In that regard, different settings and widths of riparian buffer zones (12, 24, 36, 48 and $60 \mathrm{~m}$ ) with woody vegetation, shrubs or grasses were assessed. The methodology was comprised of the evaluation of a large number of experimental sites and the sampling was conducted after the first rain period and respective fertilizer applications. The results point to the fact that effectiveness is largely controlled by buffer zone width and vegetation type. Indeed, buffer zones with $60 \mathrm{~m}$ width composed of woody soils were more effective in phosphorus (99.9\%) and nitrogen (99.9\%) removal when compared to shrub (66.4\% and $83.9 \%$, respectively) or grass vegetation ( $52.9 \%$ and $61.6 \%$, respectively) areas. Woody vegetation has deep rooting systems and woody soils have a higher content of organic matter when compared to grass and shrubs areas.
\end{abstract}

(ㄷ) 2014 Elsevier B.V. All rights reserved.

\section{Introduction}

Technological advances in the agricultural sector have improved global food and fibers production. However, the leaching of nutrients from fertilization practices is one of the leading causes of the degradation of current aquatic ecosystems (Groffman et al., 2002; Gunningham and Sinclair, 2005). In temperate and subtropical zones the problems are intensified because increasing fertilization processes are required (Syversen and Borch, 2005; Reynolds-Vargas et al., 2006). Indeed, these soils are exposed to long periods of weathering, which results in nutrient-poor soils with little organic matter, low-capacity cation-exchange, high in iron and aluminum oxides with a slightly acid $\mathrm{pH}$ (Theodoro and Leonardos, 2006). No-till cropping system is a conservation farming technique in which the planting is done without the steps of conventional tillage plowing and harrowing (Humberto et al., 2011) and has been advocated because it favors the increase in nutrients

\footnotetext{
* Corresponding author at: Federal University of Paraná, Centro Politécnico, Hydrogeological Research Laboratory, 81990-551 Curitiba, PR, Brazil.

Tel.: +55 419765 1930; fax: +55 4132677910 .

E-mail address: terenciojunior@gmail.com (T.R. Aguiar Jr.).
}

levels, particularly in the soil surface layer (Schröder et al., 2004; Syversen, 2005). This system always keeps the soil covered with growing plants and plant residues. The coverage is intended to protect the soil from the impact of raindrops, runoff and erosion from water and wind (Schröder et al., 2004). Due to the drastic reduction of erosion, the potential for contamination of the environment offers the largest farmer income. This is because the stability of production is enlarged compared to traditional methods of soil management (Bertol et al., 2005; Humberto et al., 2011).

In order to address this risks of surface water and groundwater contamination by nutrient rich waters, riparian buffer zones have been extensively prescribed. Indeed, these natural engineering systems protect river banks from erosion and may capture water contaminants by physical, chemical and biological processes (Dillaha et al., 1989; Ahola, 1990; Syversen, 2002, 2005; Hefting et al., 2005; Stutter et al., 2009). The use of riparian buffer zones in large areas with intensive agriculture as a mitigation measure for nutrient removal has been questioned primarily due to the existence of few studies addressing the removal effectiveness from agricultural leachates in soil layers of riparian vegetation. This is notable in south-American agricultural regions (Stutter et al., 2009; Ruschel et al., 2009). In addition, most have been conducted by targeting runoff after coordinated simulated flow events using 
artificial rain. Simulations were not conducted using natural or real conditions (Sharpley et al., 1986; Mcdowell et al., 2007).

Therefore, knowledge about the performance in full-scale buffer zones located in tropical and warm-temperate areas is scarce. The objective of this study is to evaluate the contaminants removal capacity of the riparian buffers associated with no-till cropping in temperate climates. We further intend to provide efficient designs for management of agricultural zones and conservation of aquatic ecosystems.

\section{Materials and methods}

\subsection{Characterization of the study area}

The river Cará-Cará is located in the southeastern portion of Ponta Grossa, in Paraná state of Brazil (Fig. 1). The Cará-Cará river is a tributary of the Tibagy river, which has a drainage area of $73 \mathrm{~km}^{2}$ and is part of the Tibagy river basin (Fig. 1).

The main agricultural use in the Cará-Cará river basin is primarily for tillage crops; specifically corn and soybeans. Therefore, representative locations selected in the present study had the same soil characteristics, oxisols, with a percentage of $30 \%$ clay and high permeability, and 8-9\% slope (Ponta Grossa, 2012). The annual rainfall is about $1650 \mathrm{~mm}$ and the average annual temperature $18{ }^{\circ} \mathrm{C}$ $( \pm 2)$ (Fig. 2). The climate of the study area is classified as temperate climate (Cfb) according to the Köppen classification (Ponta Grossa, 2012).

According to Fig. 2, corn and maize cropping utilized in the study area followed these steps: Crop $>$ Fallow $>$ desiccation and planting $>$ Growth $>$ Crop $>$ Fallow. The soil was manipulated only at planting time, when a furrow was opened to deposit seeds and fertilizers. This cultivation method is very important for the success of crop rotation, providing nutrient conservation and contributing to pests, diseases and weeds control (Stutter et al., 2009). It is worthwhile to note that the Brazilian Forestry Code prescribes that all farms must leave a riparian zone space between agriculture and the riverbank (Brasil, 2012). The riparian zone must be at least $15 \mathrm{~m}$ for rivers and up to $10 \mathrm{~m}$ wide. For rivers with widths larger than $10 \mathrm{~m}$, the recovery should occur in sites corresponding to half the width of the river, subject to a minimum of $30 \mathrm{~m}$ and a maximum of $100 \mathrm{~m}$.

\subsection{Methods of sampling}

A total of 27 study sites were selected with riparian buffers having approximate widths of 12,36 and $60 \mathrm{~m}$. Nine sites were established for each of three different dominant vegetation types: woodland, shrubs and grasses, containing a triplicate transept for each width $(12 \mathrm{~m}, 36 \mathrm{~m}$ and $60 \mathrm{~m})$. The woody vegetation is characterized as alluvial rain forest, with a predominance of trees with a height range of $15-20 \mathrm{~m}$. The predominant species are: Sebastiania commersoniana, Anadenanthera colubrina, Vernonia discolor, Jacaranda puberula, Syagrus romanzoffiana, Ilex theezans, Ocotea porous Ocotea odorifera, Cedrela fissilis and Tabebuia alba. The shrubby plants are small with a maximum height of $3 \mathrm{~m}$. The predominant species are: Miconia sellowiana, Miconia hyemalis, Erythroxylum microphyllum and Petunia rupestris. Among the grasses, the most common genera are Andropogon and Aristida, especially represented by Aristida pallens, Chloris bahiensis and Andropogon bicornis. The latter is considered a colonizing species of degraded areas (Ruschel et al., 2009). In each study site, transepts were established between the crop limit and the river channel. Water was collected from piezometers with a ground water level of 3-4 m. The sampling wells were made with drilling machines and a Dutch auger.
Sampling was performed four times following crop phenology and the crop events of nutrient applications (Fig. 2), giving a population of 12 values $(n=12)$. Water sampling was performed following the first rain period and after applications of nitrogen, phosphorus and potassium fertilizers (Fig. 2). Sampling occurred during periods of rain and drought with two samplings per year during the rainy season (March and April 2013/2014) and two samplings per year in the dry season (May and June 2013/2014). Rainfall ranged from 25 to $74 \mathrm{~mm}$ in the rainy season and $27-55 \mathrm{~mm}$ in the dry season (Fig. 2). Water was removed using a vacuum pump, and after each collection the pump and tubes were cleaned with distilled water. The first $500 \mathrm{~mL}$ of water was discarded before each sample in order to obtain representative samples.

\subsection{Analysis}

The values of the physical-chemical parameters dissolved oxygen, electrical conductivity, $\mathrm{pH}$, oxidation-reduction potential, salinity, temperature and depth were determined in situ using a multi-parameter AP-7000 AquaProbe. All samples were stored in polypropylene bottles and preserved at $4{ }^{\circ} \mathrm{C}$ for further analysis in the laboratory. In addition, the samples were comprised of nitrogen $(\mathrm{N})$, nitrates $\left(\mathrm{NO}_{3}{ }^{-}\right)$, nitrites $\left(\mathrm{NO}_{2}{ }^{-}\right)$, phosphorus $(\mathrm{P})$ and potassium $\left(\mathrm{K}^{+}\right)$. They were also tested for alkalinity, as well as hardness, free carbon dioxide $\left(\mathrm{CO}_{2}\right)$, carbonates $\left(\mathrm{CO}_{3}{ }^{-2}\right)$, chlorides $\left(\mathrm{Cl}^{-}\right)$, fluoride $\left(\mathrm{F}^{-}\right)$, sulfate $\left(\mathrm{SO}_{4}{ }^{-2}\right)$, calcium $\left(\mathrm{Ca}^{+2}\right)$, magnesium $\left(\mathrm{Mg}^{+2}\right)$, sodium $\left(\mathrm{Na}^{+}\right)$and dissolved silica $\left(\mathrm{SiO}_{2}\right)$. Analyses were performed according to Standard Methods (APHA, 2012). For quality control, analytical reagents provided by Sigma Aldrich were used with a purity of 99.9\%. 30 samples were also collected in duplicate and analyzed by an independent laboratory to confirm the results.

The significance of different samples was tested by analysis of variance (ANOVA). When results were shown to be significant, Tukey's multiple comparison tests were run to determine which buffer zone width were significantly different by least significant difference (LSD) at the 5\% level using the Origin Pro 9.0 (OriginLab Corporation, USA) and Statistic (Version 10, StatSoft, USA).

\subsection{Runoff determination}

Runoff sampling was performed using study plots with $2 \mathrm{~m}$ wide and $5 \mathrm{~m}$ in length, where the area of each experimental plot had $5 \mathrm{~m}^{2}$. The samples were enclosed by sheet-metal of $10 \mathrm{~cm}$ height and $5 \mathrm{~cm}$ buried in the ground. The plots were allocated following the slope being the lower end, the last one meter built in a " $\mathrm{V}$ " formation where the flow was channeled to a bucket. The average accumulated rainfall was measured with the use of a portable weather station Vantage Vue Davis, installed near the study area. The volume of water was calculated according to the area of the experimental plot, with the percentage of retained (or infiltrated) water calculated as the difference between the volume of the plot and the volume of runoff collected.

\section{Results}

The results obtained in the different study periods (March-June 2013 and 2014) showed no significant differences, thus the data were used together. There were no significant differences $(p>0.05)$, using Tukey's test, between the different sampling points regarding nitrites $\left(\mathrm{NO}_{2}^{-}\right)$, potassium $\left(\mathrm{K}^{+}\right)$, alkalinity, hardness, free carbon dioxide $\left(\mathrm{CO}_{2}\right)$, carbonates $\left(\mathrm{CO}_{3}{ }^{-2}\right)$, chloride $\left(\mathrm{Cl}^{-}\right)$, fluoride $\left(\mathrm{F}^{-}\right)$, sulphates $\left(\mathrm{SO}_{4}{ }^{-2}\right)$, calcium $\left(\mathrm{Ca}^{+2}\right)$, magnesium $\left(\mathrm{Mg}^{+2}\right)$, sodium $\left(\mathrm{Na}^{+}\right)$ and dissolved silica $\left(\mathrm{SiO}_{2}\right)$. In addition, these elements were within the typical values for the region (Zimmermann et al., 2008).

Table 1 shows the nutrient concentrations from the samples collected at $12 \mathrm{~m}, 36 \mathrm{~m}$ and $60 \mathrm{~m}$ after the agricultural zone, 


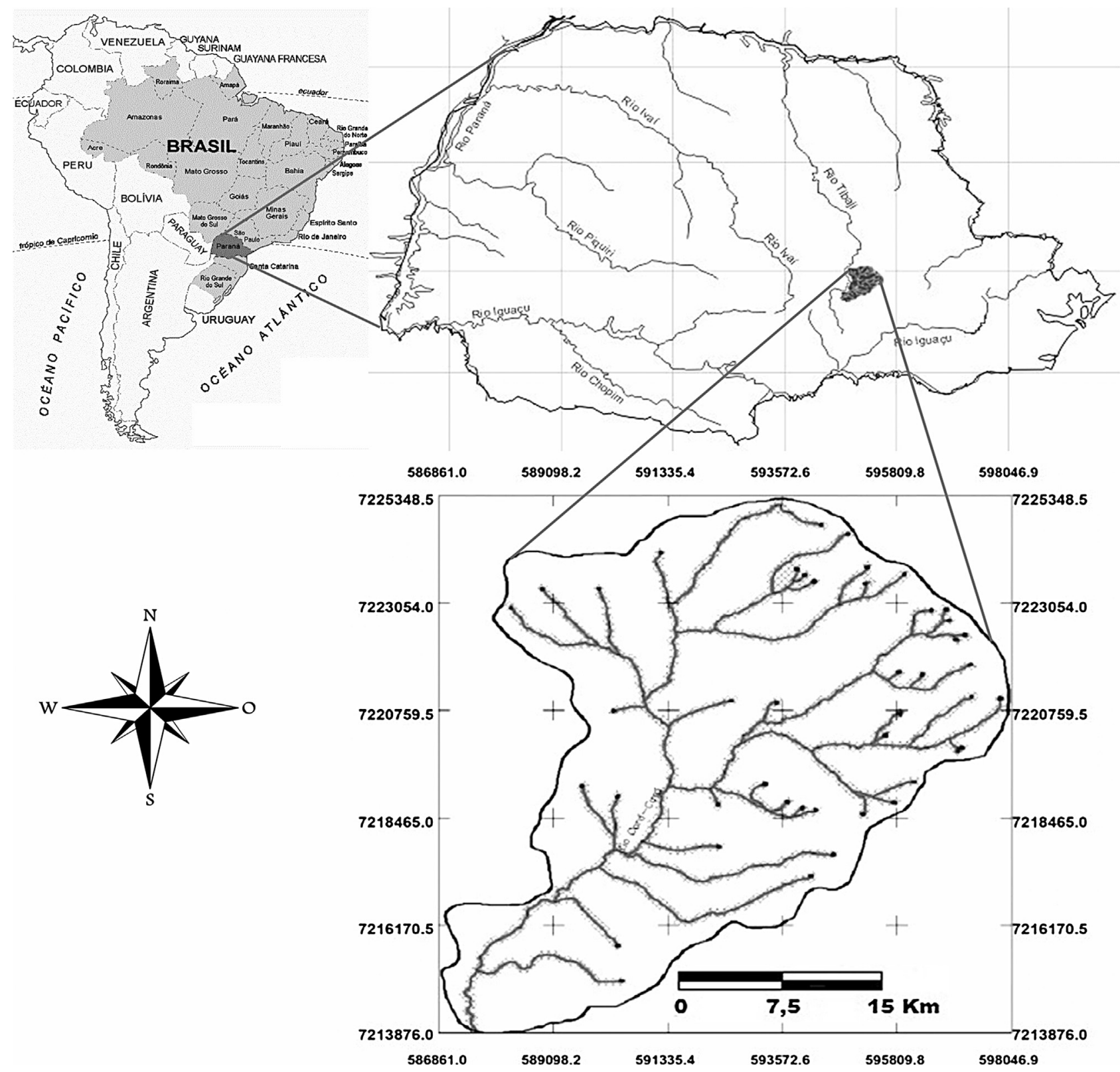

Fig. 1. Map of Cará-Cará river watershed.

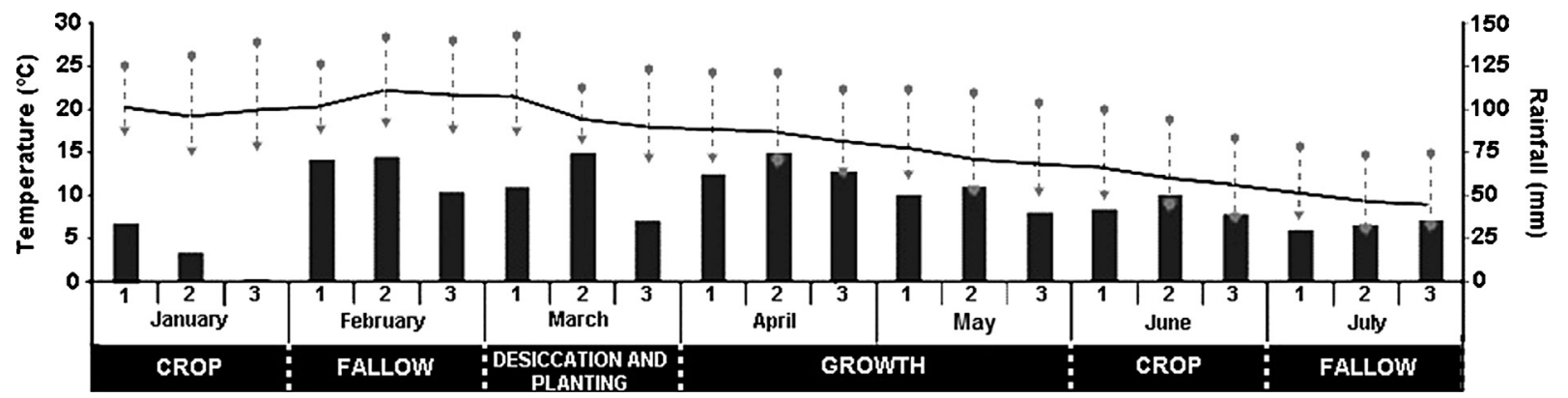

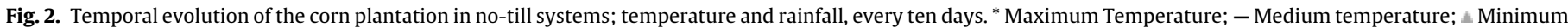
temperature. Vertical bars indicate rainfall.

in regions composed by woody vegetation, shrubs and grasses, separately. In the buffer zone composed of woody vegetation, the removal of $\mathrm{N}, \mathrm{P}$ and $\mathrm{NO}_{3}{ }^{-}$were significantly higher than in areas with grasses and shrubs. For the other nutrients, no significant differences were observed between the buffer zones (Table 1). Using the Tukey analysis it was possible to compare the averages of local width of $12 \mathrm{~m}, 36 \mathrm{~m}$ or $60 \mathrm{~m}$, composed of grasses (shrubby or woody). All areas composed of grasses, shrubby or woody showed 
Table 1

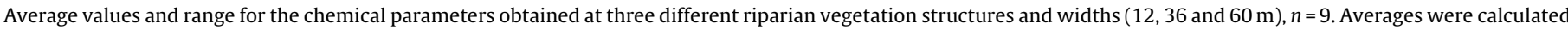
using data collected in triplicate for four sampling periods.

\begin{tabular}{|c|c|c|c|c|c|c|c|c|c|}
\hline \multirow[t]{2}{*}{ Parameters } & \multicolumn{3}{|l|}{ Woody } & \multicolumn{3}{|l|}{ Shrub } & \multicolumn{3}{|l|}{ Grasses } \\
\hline & $12(\mathrm{~m})$ & $36(\mathrm{~m})$ & $60(\mathrm{~m})$ & $12(\mathrm{~m})$ & $36(\mathrm{~m})$ & $60(\mathrm{~m})$ & $12(\mathrm{~m})$ & $36(\mathrm{~m})$ & $60(\mathrm{~m})$ \\
\hline $\mathrm{N}\left(\mathrm{mg} \mathrm{L}^{-1}\right)$ & $23.6( \pm 2.0)^{d}$ & $2.55( \pm 0.2)^{\mathrm{e}}$ & $0.03( \pm 0.06)^{\mathrm{a}}$ & $25.0( \pm 1.3)^{\mathrm{d}}$ & $11.4( \pm 0.8)^{\mathrm{e}}$ & $6.9( \pm 0.7)^{\mathrm{a}}$ & $32.0( \pm 1.4)^{\mathrm{d}}$ & $30.3( \pm 1.8)^{\mathrm{e}}$ & $16.1( \pm 2.5)^{\mathrm{a}}$ \\
\hline $\mathrm{P}\left(\mu \mathrm{gL}^{-1}\right)$ & $13.9( \pm 0.5)^{\mathrm{f}}$ & $1.7( \pm 0.4)^{\mathrm{g}}$ & $0.03( \pm 0.02)^{\mathrm{b}}$ & $18.8( \pm 0.8)^{\mathrm{f}}$ & $13.8( \pm 0.7)^{\mathrm{g}}$ & $4.0( \pm 0.6)^{b}$ & $23.4( \pm 0.9)^{\mathrm{f}}$ & $23.5( \pm 0.7)^{g}$ & $15.1( \pm 0.8)^{\mathrm{b}}$ \\
\hline $\mathrm{NO}_{3}{ }^{-}\left(\mathrm{mg} \mathrm{L}^{-1}\right)$ & $13.8( \pm 0.5)^{\mathrm{h}}$ & $2.3( \pm 0.6)^{\mathrm{i}}$ & $0.008( \pm 0.01)^{c}$ & $23 \pm(1.5)^{\mathrm{h}}$ & $15.3( \pm 0.7)^{\mathrm{i}}$ & $7.9( \pm 1.1)^{c}$ & $31.9( \pm 1.7)^{\mathrm{h}}$ & $25.1( \pm 1.4)^{\mathrm{i}}$ & $19.2( \pm 0.8)^{\mathrm{c}}$ \\
\hline $\mathrm{NO}_{2}-\left(\mathrm{mg} \mathrm{L}^{-1}\right)$ & $0.2( \pm 0.1)$ & $0.2( \pm 0.1)$ & $0.1( \pm 0.1)$ & $0.05( \pm 0.05)$ & $0.09( \pm 0.05)$ & $0.02( \pm 0.01)$ & $0.2( \pm 0.1)$ & $0.1( \pm 0.1)$ & $0.09( \pm 0.04)$ \\
\hline $\mathrm{K}^{+}\left(\mathrm{mg} \mathrm{L}^{-1}\right)$ & $0.4( \pm 0.3)$ & $0.6( \pm 0.3)$ & $0.4( \pm 0.3)$ & $0.6( \pm 0.4)$ & $0.6( \pm 0.4)$ & $0.5( \pm 0.4)$ & $0.5( \pm 0.3)$ & $0.7( \pm 0.3)$ & $0.4( \pm 0.3)$ \\
\hline $\mathrm{Mg}^{2+}\left(\mathrm{mg} \mathrm{L}^{-1}\right)$ & $2.4( \pm 0.2)$ & $2.5( \pm 0.2)$ & $2.5( \pm 0.3)$ & $2.3( \pm 0.2)$ & $2.7( \pm 0.2)$ & $2.5( \pm 0.2)$ & $2.1( \pm 0.1)$ & $2.4( \pm 0.1)$ & $2.3( \pm 0.2)$ \\
\hline $\mathrm{Ca}^{+2}\left(\mathrm{mg} \mathrm{L}^{-1}\right)$ & $4.0( \pm 0.7)$ & $4.1( \pm 0.6)$ & $4.2( \pm 0.3)$ & $3.9( \pm 0.8)$ & $4.1( \pm 0.8)$ & $4.1( \pm 0.5)$ & $3.6( \pm 0.6)$ & $4.0( \pm 0.8)$ & $3.9( \pm 0.4)$ \\
\hline $\mathrm{pH}$ & $5.0( \pm 0.2)$ & $4.9( \pm 0.2)$ & $5.1( \pm 0.2)$ & $4.8( \pm 0.5)$ & $4.9( \pm 0.2)$ & $5.2( \pm 0.3)$ & $4.5( \pm 0.5)$ & $4.7( \pm 0.1)$ & $4.9( \pm 0.3)$ \\
\hline
\end{tabular}

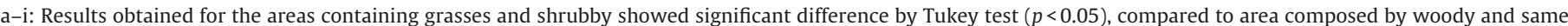
width.

significant differences $(p<0.05)$ for the concentrations of $\mathrm{N}, \mathrm{NO}_{3}{ }^{-}$ and $\mathrm{P}$ comparing the same buffer zone widths. For $\mathrm{NO}_{2-}, \mathrm{K}^{+}, \mathrm{Mg}^{2+}$ $\mathrm{Ca}^{+2}$, and $\mathrm{pH}$ were no significant differences observed in different buffer zones composition but the same width.

Regarding nitrogen $(\mathrm{N})$, phosphorus $(\mathrm{P})$, and nitrates $\left(\mathrm{NO}_{3}{ }^{-}\right)$, significant differences were found $(p<0.05)$, between different distances of the agricultural area (Fig. 3 ).

Fig. 3 shows the distribution of the values of efficiency removal for $\mathrm{N}, \mathrm{P}$, and $\mathrm{NO}_{3}{ }^{-}$grouped into vegetation types from a range of widths $(12,36$, and $60 \mathrm{~m})$. The efficiency values were obtained by relating the analyzed data for concentration points with the concentration at the zero point. For a vegetation strip of $60 \mathrm{~m}$ (Fig. 3), the woody vegetation obtained a retention capacity of $100 \%$ for $\mathrm{N}, \mathrm{P}$ and $\mathrm{NO}_{3}{ }^{-}$. The shrub vegetation obtained $83 \%$ for removal of $\mathrm{N}, 66 \%$ for $\mathrm{P}$ and $80 \%$ for $\mathrm{NO}_{3}{ }^{-}$. In the grass buffers, there was retention of $61 \%$ for $\mathrm{N}, 53 \%$ for $\mathrm{P}$ and $52 \%$ for $\mathrm{NO}_{3}{ }^{-}$. For the vegetation strip of $36 \mathrm{~m}$ (Fig. 3), woody vegetation was efficient in removing $93 \% \mathrm{~N}, 92 \% \mathrm{P}$ and $94 \%$ of $\mathrm{NO}_{3}{ }^{-}$. The $\mathrm{N}$ removal efficiency when the shrub vegetation was present in the buffer zone was $56 \%$ for $\mathrm{P}$, and $46 \%$ to $61 \%$ for $\mathrm{NO}_{3}{ }^{-}$. However, when the buffer zone consisted of grass, there was a removal power of $41 \%$ for $\mathrm{N}, 34 \%$ for $\mathrm{P}$ and $37 \%$ for $\mathrm{NO}_{3}{ }^{-}$. In the range of $12 \mathrm{~m}$ (Fig. 3 ) the effective removal for woody vegetation was calculated at $43 \%$ for $\mathrm{N}, 36 \%$ for $\mathrm{P}$ and $65 \%$ for $\mathrm{NO}_{3}{ }^{-}$. For the shrub vegetation, the removal efficiency was $41 \%$ for $\mathrm{N}, 32 \%$ for $\mathrm{P}$ and $42 \%$ for $\mathrm{NO}_{3}{ }^{-}$. In the grass area, removal efficiency was $21 \% \mathrm{~N}, 17 \% \mathrm{P}$ and $20 \% \mathrm{NO}_{3}{ }^{-}$.
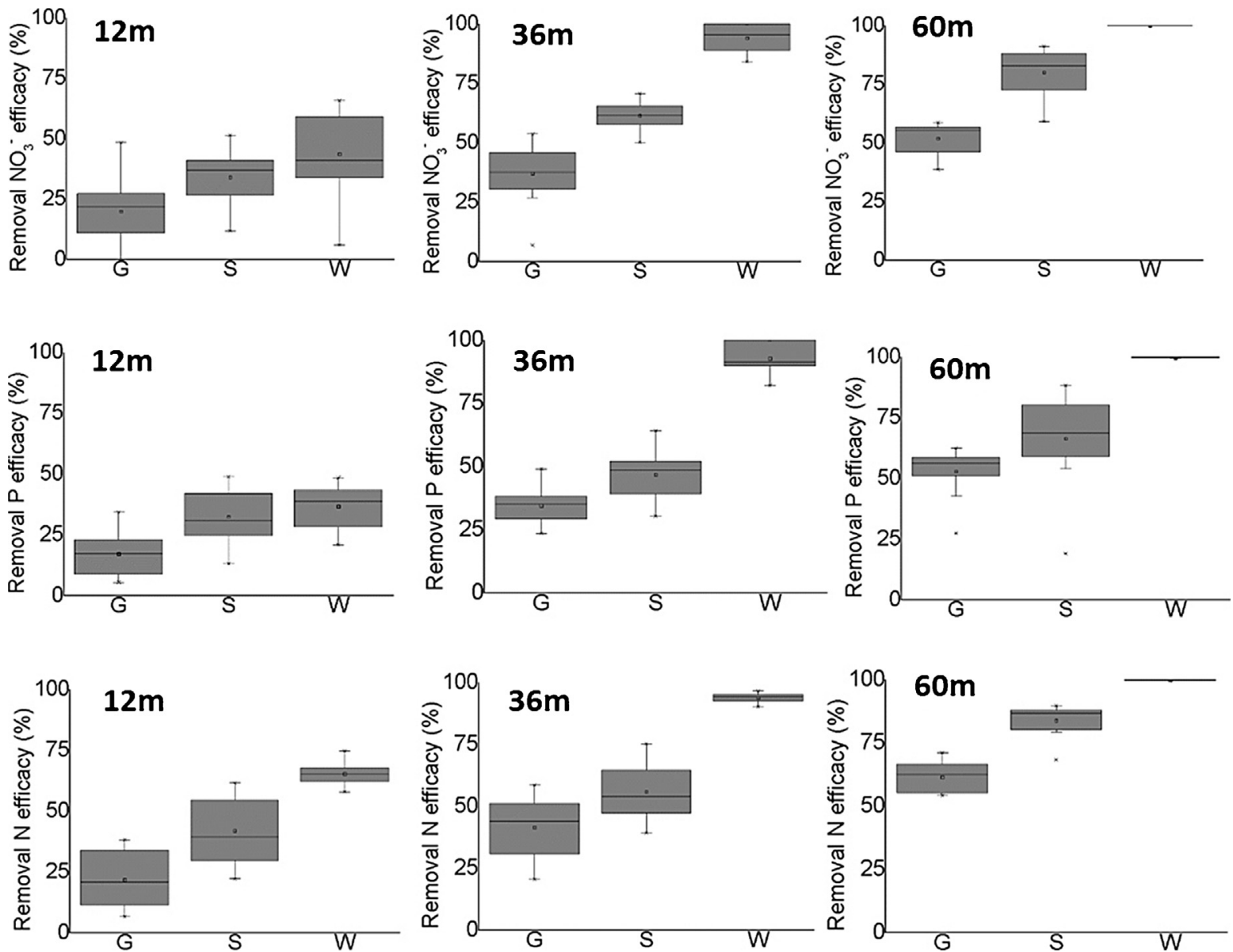

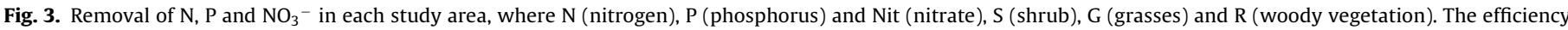
was calculated in the following buffer zone widths (A) $0-12 \mathrm{~m}$ (B) $0-36 \mathrm{~m}$, and (C) $0-60 \mathrm{~m}$. 


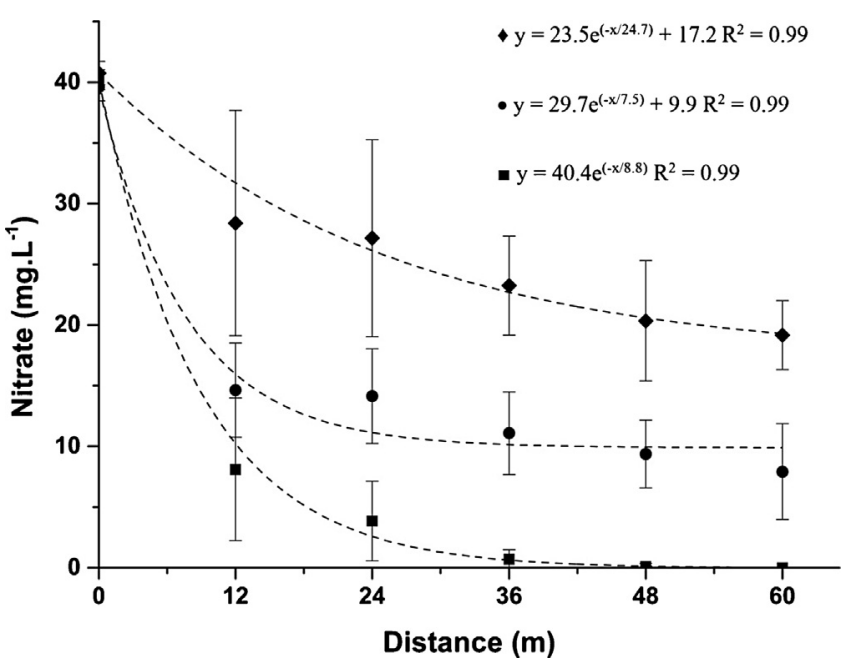

Fig. 4. Relation between nitrate concentration $\left(\mathrm{mg} \mathrm{L}^{-1}\right)$ and the distance of the sampling points in the buffer zones, using widths between 0 and $60 \mathrm{~m}$. Nitrate concentration was measured in areas with buffer zone composed of $\bullet$ Grasses, $\bullet$ Shrub or Woody.

Vegetation strips with $60 \mathrm{~m}$ width obtained the best removal efficiency of all vegetation types studied, especially for nitrogen. There was a significant reduction of the nutrients using Tukey's test. For the woody vegetation, removal reached in $100 \%$ with a $60 \mathrm{~m}$ buffer zone. Comparing the removal obtained for buffer zones of different composition and different widths, the $\mathrm{N}, \mathrm{P}$ and $\mathrm{NO}_{3}{ }^{-}$ showed significant differences for removal obtained in buffer zones of $60 \mathrm{~m}$, composed of grasses, shrubby and woody vegetation. The lowest filtering effect was observed for the buffer zone composed of grasses, both for $\mathrm{N}, \mathrm{P}$ and $\mathrm{NO}_{3}{ }^{-}$, where removal after $60 \mathrm{~m}$ were only $62 \%$ and $52 \%$, respectively.

The relation between nitrate concentration and distance to the crop in areas with a buffer zone of $60 \mathrm{~m}$ can be observed in Fig. 4.

The buffer zone composed by grasses showed a maximum $52 \%$ removal of nitrate, keeping a minimum concentration of $19 \mathrm{mg} \mathrm{L}^{-1}$. For grasses buffer zone (Fig. 4), the correlation coefficient $\left(R^{2}\right)$ was 0.99 for exponential decay regression. The analysis of variance (ANOVA) showed significant $(p<0.05)$ differences only between the initial and final points of collection. The values obtained for the samples collected at the point of $12 \mathrm{~m}$ to $60 \mathrm{~m}$ showed no significant difference $(p>0.05)$. In the buffer zone composed of shrubby vegetation (Fig. 4), the maximum nitrate removal observed was $80 \%$, with a minimum concentration of nitrate at $10 \mathrm{mg} \mathrm{L}^{-1}$. The $R^{2}$ was 0.99 . The analysis of variance (ANOVA) showed significant differences $(p<0.05)$ to the nitrate concentration between the start and end points of collection. When the buffer zone analyzed was composed of woody vegetation (Fig. 4), the nitrate removal reached $100 \%$ when $60 \mathrm{~m}$ away from the agricultural zone, and the correlation coefficient $\left(R^{2}\right)$ of the exponential equation was 0.99 . From the results was possible to determine the nitrate removal in buffer zone composed of grasses, shrubby and woody (Fig. 4) adjusted by an exponential decay equation. Hence, nitrate removal efficiency increases with the width of the buffer zone and the complexity of the vegetation structure.

Similar analyzes were performed regarding the concentration of nitrogen (Fig. 5). For buffer zones consisting of grasses, the minimum concentration of nitrogen observed was $15 \mathrm{mg} \mathrm{L}^{-1}$. For buffer zones consisting of shrubby vegetation the minimum was $4 \mathrm{mg} \mathrm{L}^{-1}$ and for woody vegetation, the removal was $100 \%$.

The analysis of variance (ANOVA) showed significant differences $(p<0.05)$ to the concentration of nitrogen between the start and end points of collection for shrubby and woody vegetation. For grasses,

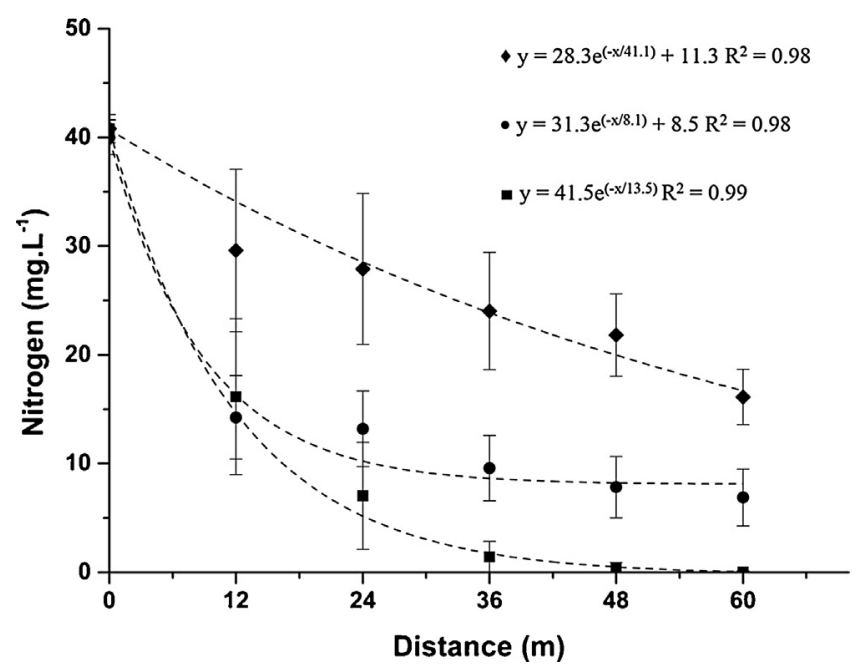

Fig. 5. Relation between the concentration of nitrogen $\left(\mathrm{mg} \mathrm{L}^{-1}\right)$ and the distance of the sampling points in the buffer zones, utilizing widths between 0 and $60 \mathrm{~m}$, where the zero point is after 60 agriculture and the river. Nitrogen concentration was measured in areas with buffer zone composed of $\downarrow$ Grasses, $\bullet$ Shrub or $\square$ Woody.

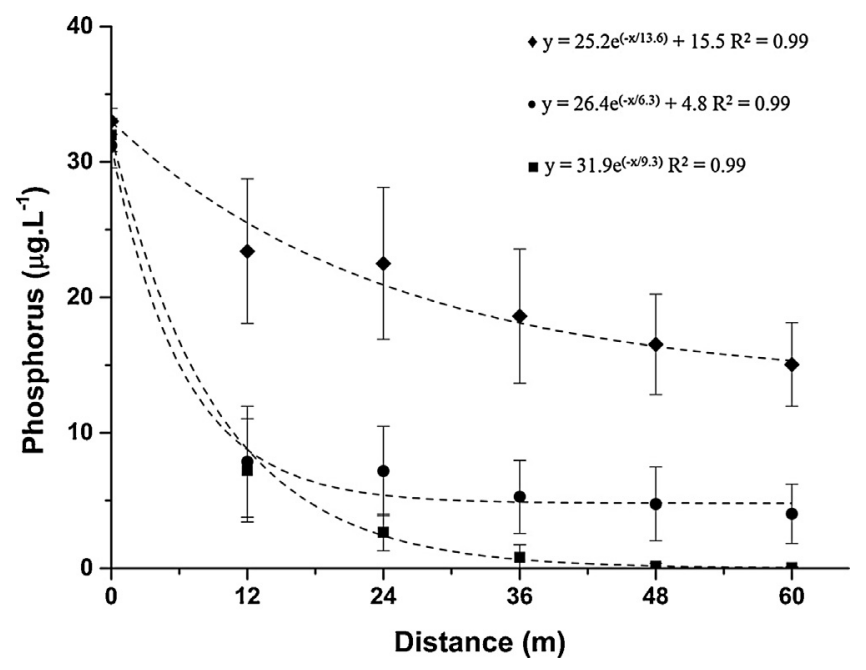

Fig. 6. Relation between phosphorus concentration $\left(\mu \mathrm{gL}^{-1}\right)$ and the distance of the sampling points in the buffer zones, utilizing widths between 0 and $60 \mathrm{~m}$, where the zero point is after $60 \mathrm{~m}$ agriculture and the river. Phosphorus concentration was measured in areas with buffer zone composed of $\bullet$ Grasses, • Shrub or $\boldsymbol{\square}$ Woody.

no significant differences were observed $(p>0.05)$ between $12 \mathrm{~m}$ and $60 \mathrm{~m}$ collected samples. For grasses and shrubby, the $R^{2}$ was 0.98 , for woody the $R^{2}$ was 0.99 . The nitrogen removal in buffer zone composed for grasses, shrubby and woody is shown in Fig. 5.

For the analysis of phosphorus (Fig. 6), when the study area was composed of grasses, the minimum concentration observed was $12 \mu \mathrm{g} \mathrm{L}^{-1}$. When the buffer zone consisted of shrub vegetation, a lower phosphorus concentration of $4 \mu \mathrm{g} \mathrm{L}^{-1}$ was observed. For the woody buffer zone, no phosphorus concentration was observed after $60 \mathrm{~m}$. The analysis of variance (ANOVA) showed significant differences $(p<0.05)$ to the concentration of phosphorus between the start and end points of collection for grasses, shrubby and woody vegetation.

In all the cases, the relation between phosphorus concentration reduction in the buffer zone composed for grasses, shrubby and woody is proportional to an increase in the width of the buffer zone. The removal of nitrogen, nitrate and phosphorus increases in the following order: grasses $>$ shrub vegetation $>$ woody vegetation. The buffer zone consisting of woody vegetation was more efficient 
in removing nitrate, phosphorus and nitrogen residual present in groundwater originated from the agricultural areas, as opposed to non-woody riparian zones. In this work, a nitrate removal of $98 \%$ was observed with the same width of woody vegetation. A significant difference $(p<0.05)$ between the points of grass, shrubs and woody vegetation for the $\mathrm{NO}_{3}{ }^{-}$was noticed. In the $36 \mathrm{~m}$ buffer zone composed of woody vegetation, removal was $98 \%$ greater than that observed for shrub (72\%) and grass (42\%). Buffer zones consisting of grass or shrub presented a retention performance smaller than the buffer zone composed of woody vegetation and the riparian zone showed the lowest runoff. The values ranged from 2.7 to $5.4 \%$ cumulative retention of rain water and higher runoff capacity subsurface, reaching $94.5 \%( \pm 0.9)$ infiltration. The region composed of shrub presented a runoff retention of $9.3 \%( \pm 2.3)$ and sub-surface infiltration of $90.7 \%( \pm 2.1)$ The region composed of grasses had the highest runoff, reaching $14.2 \%( \pm 3.4)$ retention and less infiltration with $85.8 \%( \pm 2.6)$.

\section{Discussion}

The woody vegetation zone has a higher nutrient retention capacity (99.9\%). Soils with such vegetation have a higher content of organic matter when compared to areas of grass and shrubs, due to leaves and wood that are deposited and degraded in the soil (Young et al., 1980; Groffman et al., 2002). The organic matter has good nutrient adsorption characteristics due to a complex system of carbonic substances and processes of humus stabilization (Cahn et al., 1992). The soil and woody vegetation ecosystem contains a rich microbial population (Groffman et al., 2002). The areas of woody vegetation have a deep rooting system that reaches the saturated soil zone and removes nitrogen compounds (Groffman et al., 2002; Mayer et al., 2007). The riparian vegetation consisting of woody vegetation also showed a reduction in $\mathrm{P}$ concentration and nitrogen. This reduction can be explained by the high sediment retention and high concentration of organic matter to where the P and nitrogen can be adsorbed (Sharpley et al., 1994; Mankin et al., 2007; Mcdowell et al., 2007; Stutter et al., 2009).

The results obtained for runoff corroborate the results obtained for nutrient removal. In regions with riparian vegetation composed of trees, the infiltration rate is higher and erosion is lower. Because the soil is protected by trees and related biomaterial, the water drops impact in the soil is reduced and the higher infiltration rates hinder the transport of nutrients through runoff. However, in regions composed of grasses, the impact of rain on unprotected soil causes a greater nutrient runoff dragging toward the river. Areas of study composed of shrubs had an intermediate pattern.

The removal capacity in buffer zones of $60 \mathrm{~m}$ allowed the removal of all chemical elements up to non-detectable levels. Similar results were observed (Lee et al., 2000) when evaluating the ability of different species of riparian vegetation for nutrient retention. For nitrate, however, the same authors observed that woody vegetation with $20 \mathrm{~m}$ width had a good capacity for removing pollutants, with an efficiency of $65 \%$. The riparian zone composed of shrubs and grasses did not obtain good results when compared with areas composed of woody vegetation (Young et al., 1980; Mankin et al., 2007). Areas comprised of grasses and shrubs have a small amount of organic soil matter $(<4.5 \%)$ and lower microbial activity due to the lack of shade and vegetable scraps. Thus, the soil remains unprotected, which increases the surface runoff, thus increasing the sediment transport. Hence, the contact time between pollutants, vegetation and soil is lower, increasing the area of dispersion of pollutants, especially of $P$ that is transported by sediment and adsorbed by the surface charges of clay minerals and organic matter (Sharpley et al., 1994).
The adoption of no-till system, affects the dynamics of $\mathrm{P}$ and $\mathrm{N}$ in the soil, mainly due to the lack of soil disturbance and excess organic matter that increases the contact between the colloids and the ions $\mathrm{P}$ and $\mathrm{N}$, increasing the adsorption, favoring processes of mineralization and nitrification (Cahn et al., 1992; Chen and Hong, 2011). These conditions, combined with short rainfall, but with strong intensity in the study area and a large excess nitrogen and phosphorus, lead to the accumulation of nitrate and high losses by subsurface leaching (Groffman et al., 2002; Chen and Hong, 2011). Numerous studies have shown that yield from agriculture does not increase significantly when high rates of fertilizer application exceeds a certain value, however contamination and residual nitrate and nitrogen increases sharply in the saturated soil zone (Syversen, 2002; Schröder et al., 2004; Hefting et al., 2005; Grismer et al., 2006; Chen and Hong, 2011). In the study area used in this work, the nitrogen $\left(42 \mathrm{mg} \mathrm{L}^{-1}\right)$ and nitrate $\left(44 \mathrm{mg} \mathrm{L}^{-1}\right)$ were the main contaminants of the saturated soil zone. Concentrations of nitrate and nitrogen had a good reduction for riparian zone composed of woody vegetation, with $36 \mathrm{~m}$ width, reaching $3 \mathrm{mg} \mathrm{L}^{-1}$ and $1 \mathrm{mg} \mathrm{L}^{-1}$, respectively. Considered the nutrients studied, nitrate is the nitrogen most stable form which is more significant in terms of water resources contamination and human health. For instance, regarding Brazilian (Brasil, 2011) and USA legislation (EPA, 2009) both suggest a maximum concentration of $10 \mathrm{mg} \mathrm{L}^{-1}$ of $\mathrm{N}-\mathrm{NO}_{3}$ Thus the riparian vegetation composed of woody with a width of $36 \mathrm{~m}$ were appropriate to prevent surface and ground water contamination. A higher nitrogen and nitrate removal rate in riparian areas was also reported by other researchers (Borin et al., 2005; Hefting et al., 2005; Lovell and Sullivan, 2006).

Other studies in Europe and the United States had similar results despite the different climatic conditions (Wenger, 1999; Borin et al., 2005; Hefting et al., 2005). These authors pointed out that widths smaller than $10 \mathrm{~m}$ provide only a limited protection against the nitrate contamination of water resources. Therefore, riparian vegetation consisting of woody vegetation with a width higher than $36 \mathrm{~m}$ seem to be the minimum necessary for the maintenance of biological components responsible for the removal of micropollutants. This includes both soil and water in the saturated zones in temperate climatic areas and oxisols where the ability of the soil to retain substances was studied (Groffman et al., 2002). According to the authors, the organic substances in the soil have ability to connect and retain anions by having amino groups, peptide bonds, and other nitrogenous polypeptides. These anions, connected directly or through metals in the case of phosphates, are easily assimilated by plants. Thus, the soils of areas with woody vegetation, which are characterized by a high content of organic matter are deposited in the soil. They continue to form humic substances, which are also derived from the decomposition of organic matter.

The technique of cultivation and soil management also exerts great influence on the quality of surface and groundwater (Robertson et al., 1991). Some agricultural practices are capable of causing widespread nutrient contamination or other agricultural contaminants, particularly in areas of thin grounds, with good drainage (Muscutt et al., 1993; Uusitalo and Jansson, 2002; Gharabaghi et al., 2006). In this work, the no-till system showed excellent results by reducing runoff and the concentration of nitrogen, nitrate and phosphorus from areas between agriculture and the points of the study. This decline was observed in the areas of woody vegetation, shrub and grass.

\section{Conclusion}

The relation between the removal efficiency of agricultural nutrients by riparian buffer zones and their main characteristics in no-till systems and temperate zones was presented. Buffer width is an important factor in the removal of all pollutants, especially $\mathrm{N}$, 
$\mathrm{NO}_{3}{ }^{-}$and $\mathrm{P}$. The widths of $12 \mathrm{~m}$ had an inadequate protection for the concentration of nutrients used in the study sites. Regarding the type of vegetation, buffer zones composed of trees have a very effective removal rate of $\mathrm{N}, \mathrm{P}$ and $\mathrm{NO}_{3}{ }^{-}$compared with areas of arborous vegetation and grass. The results indicate that the design of riparian buffer zones should be conservative. The higher efficiency of woody vegetation zones of $36 \mathrm{~m}$ and $60 \mathrm{~m}$ widths, combined with agricultural economy, presents a greater potential for acceptance by rural producers, thereby facilitating the diffusion of this conservation practice in agriculture. Furthermore, the width of $36 \mathrm{~m}$ was appropriate to reduce the nitrate concentration to levels below the required values (levels) defined in the water protection legislation and regulatory standards.

\section{Acknowledgment}

This work was supported by CNPq-National Council of Technological and Scientific Development-Brazil.

\section{References}

Ahola, H., 1990. Vegetated buffer zone examinations on the Vantaa River basin. Aqua Fenn. 20, 65-69.

APHA, AWWA, WEF, 2012. Standard Methods for the Examination of Water and Wastewater, 22st ed. American Public Health Association, Washington, DC (1496).

Bertol, O.J., Rizzi, N.E., Favaretto, N., Lavoranti, O.J., 2005. Perdas de nitrogênio via superfície e subsuperfície em sistema de semeadura direta. Florest 35, 429-442.

Borin, M., Vianello, M., Zanin, G., 2005. Effectiveness of buffer strips in removing pollutants in runoff from a cultivated field in North-East Italy. Agric. Ecosyst. Environ. 105, 101-114.

Brasil, Portaria MS no. 2914 de 12 de dezembro de 2011, Brasília 2011, 40p.

Brasil, 2012. Código Florestal. Presidência da República. Lei 12.651, de 25 de maio de 2012, Brasília, pp. 32p.

Cahn, M.D., Bouldin, D.R., Cravo, M.S., 1992. Nitrate sorption in the profile of an acid soil. Plant Soil 143, 179-183.

Chen, N., Hong, H., 2011. Nitrogen export by surface runoff from a small agricultural watershed in southeast China: seasonal pattern and primary mechanism. Biogeochemistry 106, 311-321.

Dillaha, T.A., Reneau, R.B., Mostaghimi, S., Lee, D., 1989. Vegetative filter strips for agricultural nonpoint source pollution control. Trans. ASAE 32, 513-519.

EPA-Environmental Protection Agency, 2009. National primary drinking water regulations. In: Publication No. EPA 816-F-09-0004. EPA-Environmental Protection Agency, Washington, DC, pp. p.6.

Gharabaghi, B., Rudra, R.P., Goel, P.K., 2006. Effectiveness of vegetative filter strips in removal of sediments from overland flow. Water Qual. Res. J. Can. 41, 275-282.

Grismer, M.E., OíGeen, A.T., Lewis, D., 2006. Vegetative filter strips for nonpoint source pollution control in agriculture. ANR Publ. 8195, 1-7.

Groffman, P.M., Boulware, N.J., Zipperer, W.C., Pouyat, R.V., Band, L.E., Colosimo, M.F., 2002. Soil nitrogen cycling processes in urban riparian zones. Environ. Sci. Technol. 36, 4547-4552.

Gunningham, N., Sinclair, D., 2005. Policy instrument choice and diffuse source pollution. J. Environ. Law 17, 51-81.

Hefting, M.M., Clement, J., Bienkowski, P., Dowrick, D., Guenat, C., Butturini, A., Topa, S., Pinay, G., Verhoeven, J.T.A., 2005. The role of vegetation and litter in the nitrogen dynamics of riparian buffer zones in Europe. Ecol. Eng. 24, 465-482.
Humberto, B.C., Schlegel, A.J., Heer, W.F., 2011. Soil-profile distribution of carbon and associated properties in no-till along a precipitation gradient in the centra Great Plains. Agric. Ecosyst. Environ. 144, 107-116.

Lee, K.H., Isenhart, T.M., Schultz, R.C., Mickelson, S.K., 2000. Multispecies riparian buffers trap sediment and nutrients during rainfall simulations. J. Environ. Qual. 29, 1200-1205.

Lovell, S.T., Sullivan, Y.W.C., 2006. Environmental benefits of conservation buffers in the United States: evidence, promise, and open questions. Agric. Ecosyst. Environ. 112, 249-260.

Mankin, K.R., Daniel, M.N., Charles, J.B., Stacy, L.H., Wayne, A.G., 2007. Grass-shrub riparian buffer removal of sediment, phosphorus, and nitrogen from simulated runoff. J. Am. Water Resour. Assoc. 43, 1108-1116.

Mayer, P.M., Reynolds, S.K.J.R., Mccutchen, M.D., Canfield, T.J., 2007. Meta-analysis of nitrogen removal in riparian buffers. J. Environ. Qual. 36, 1172-1180.

Mcdowell, R.W., Nash, D.M., Robertson, F., 2007. Sources of phosphorus lost from a grazed pasture receiving simulated rainfall. J. Environ. Qual. 36 $1281-1288$.

Muscutt, A.D., Harris, G.L., Bailey, S.W., Davies, D.B., 1993. Buffer zones to improve water quality: a review of their potential use in UK agriculture. Agric. Ecosyst. Environ. 45, 59-77.

Ponta Grossa, 2012. Plano Diretor de Ponta Grossa. Prefeitura Municipal de Ponta grossa, pp. 110p.

Reynolds-Vargas, J., Fraile-Merino, J., Hirata, R., 2006. Trends in nitrate concentrations and determination of their origin using stable isotopes (180 and $15 \mathrm{~N}$ ) in groundwater of the western Central Valley, Costa Rica. AMBIO 35, 229-236.

Robertson, W.D., Cherry, J.A., Sudicky, E.A., 1991. Groundwater contamination from two small septic systems on sand aquifers. Groundwater 29, 82-92.

Ruschel, A.R., Mantovani, M., Reis, M.S., Nodari, R.O., 2009. Caracterização e dinâmica de duas fases sucessionais em floresta secundária da Mata Atlántica. Ver.a Árv. 33, 101-115.

Schröder, J.J., Scholefield, D., Cabral, R., Hofman, G., 2004. The effects of nutrient losses from agriculture on ground and surface water quality: the position of science in developing indicators for regulation. Environ. Sci. Policy 7, 15-23.

Sharpley, A.N., Chapra, S.C., Wedepohl, R., Sims, J.T., Daniel, T.C., Reddy, K.R., 1994 Managing agricultural phosphorus for protection of surface waters: Issues and options. J. Environ. Qual. 23, 437-451.

Sharpley, A.N., Smith, S.J., Menzel, R.G., 1986. Phosphorus criteria and water quality management for agricultural watersheds. Lake Reserv. Manage. 2 $177-182$.

Stutter, M.I., Langan, S.J., Lunsdom, D.G., 2009. Vegetated buffer strips can lead to increased release of phosphorus to waters: a biogeochemical assessment of the mechanisms. Environ. Sci. Technol. 43, 1858-1863.

Syversen, N., 2002. Effect of a cold-climate buffer zone on minimising diffuse pollution from agriculture. Water Sci. Technol. 45, 69-76.

Syversen, N., 2005. Effect and design of buffer zones in the Nordic climate: the influence of width, amount of surface runoff, seasonal variation and vegetation type on retention efficiency for nutrient and particle runoff. Ecol. Eng. 24 483-490.

Syversen, N., Borch, H., 2005. Retention of soil particle fractions and phosphorus in cold-climate buffer zones. Ecol. Eng. 25, 382-394.

Theodoro, S.C.H., Leonardos, O.H., 2006. Sustainable farming with native rocks: the transition without revolution. An. Acad. Bras. Ciênc. 78, 715-720.

Wenger, S., 1999. A Review of the Scientific Literature on Riparian Buffer Width Extent and Vegetation. Institute of Ecology. University of Georgia, Georgia, pp. 59.

Young, R.A., Huntrods, T., Anderson, W., 1980. Effectiveness of vegetated buffer strips in controlling pollution from feedlot runoff. J. Environ. Qual. 9 $483-487$.

Zimmermann, C.M., Guimaraes, O.M., Peralta-Zamora, P.G., 2008. Avaliação da qualidade do corpo hídrico do rio Tibagi na região de Ponta Grossa utilizando análise de componentes principais (PCA). Quím. Nova 31, 1727-1732. 